\title{
Model for Efficient Service Delivery in Public Service
}

\author{
Dr. Samihah Khalil \\ Dean, Ghazali Shafie Graduate School of Government \\ College of Law, Government and International Studies \\ Universiti Utara Malaysia \\ Email: samihah@uum.edu.my
}

Dr. Salihu Abdulwaheed Adelabu (Corresponding author)

School of Government, College of Law, Government and International Studies

Universiti Utara Malaysia

Email: salihu@uum.edu.my

Received: July 04, 2012 Accepted: July 28, 2012 DOI: 10.5296/jpag.v2i3.2157

\begin{abstract}
This paper aims to design a modified model for efficient and effective service delivery by governments' ministries, departments and agencies (MDAs). There are several existing models on service delivery, but it is noted that those models emphasized more on the estimates voted for social/welfare services and the outcomes of services provided by MDAs. Other variables such as managerial accountability and leadership quality are less emphasized. This paper therefore designs a modified model that integrates funding/management of resources, managerial accountability and leadership quality cum structure in order to ensure adequate, efficient and effective service delivery by MDAs of various governments. There seems to be a strong relationship between these variables in respect of service delivery. Lastly, the paper is conceptual in nature, which gives room for critique by practioners, researchers, scholars and public administrators in lieu of service delivery.
\end{abstract}

Keywords: Service Delivery, Fiscal Federalism, Decentralization, Managerial Accountability, Leadership Quality. 


\section{Introduction}

The act of governance by government through various ministries, departments and agencies (MDAs) is tending towards efficient and effective service delivery. But there seems to be many variables militating against the delivery of efficient and effective infrastructural, social and welfare services by various governments' ministries, departments and agencies. Few amongst the variables militating against efficient delivery of services in the public sector are corruption, accountability, probity, prudence, insufficient funding, government policies, government instability, leadership quality, etc. These variables need to be thoroughly studied, if efficient and effective social/welfare services are to be delivered by MDAs. Several studies on modus of operandi of improving on the delivery of social/welfare services are carried out by scholars such as Benton and Rigos (1986), Schneider and Park (1989), Salant (1991), Benton and Menzel (1991), Berman (1993), Cigler (1995), Park (1996), etc, these scholars unanimously submitted that there is critical need to improve on the efficient and effective delivery of social/welfare services by MDAs in the public services. In the same vein, studies have equally shown the use of different models for the delivery of goods and services by government's MDAs (Dettoog, 1984; Ferris \& Grady, 1988; Donahue, 1989; Stein, 1990; Clinger \& Feiock, 1997; Graves, 2000; Clifton \& Duffield, 2006; Salihu, 2011).

In view of this, scholars have developed different models that could be used by practioners to deliver efficient and effective social/welfare services through MDAs in the public sector. Few amongst these models are Quantitative Service Delivery Survey (QSDS), Public Expenditure Tracking Survey (PETS), Expenditure Service Delivery Survey (ESDS), Contracting-Out Model, Direct Labor Model, "Own-Right" Service Provision Model, Contestability Model (CM), Competitive Tendering Model (CTM), Collaborative Venture Model (CVM), etc. Most of the models mentioned in this paper emphasized the issue of finance majorly. Most of the models do not look vividly look at other variables may hinder efficient and effective delivery of social/welfare services in the public sector. Despite the fact that most of these models have strong strengths in determining the quantity and quality of services delivered by MDAs, there are other weaknesses observed in the existing models. In line with the noted weaknesses, United Nation Economic Commission for Africa (UNECA, 2007) postulated that finance, management and technical challenges continue to limit the capacity of MDAs to provide adequate services and infrastructure development. In view of UNECA statement, this paper therefore advocates for integration of funding, managerial accountability and leadership in order to make room for more coherent delivery system by MDAs. Studies have equally shown that efficient and effective service delivery depends largely on institutional reforms. The importance of institutional reform cannot be over-emphasized, while the need for greater capacity of MDAs is equally needed to deliver efficient and effective social/welfare services to the public (Rakodi, 1997; McGill, 1988; Rakodi, 2001; UN-Habibat, 2008). The institutional reforms therefore can only take place when funding, managerial accountability and leadership quality are integrated together to bring about efficient and effective service delivery to the public in the public sector (Salihu, 2011).

Modified Quantitative Service Delivery Model (MQSDM) is therefore designed using three 
major variables, viz-a-viz: funding, managerial accountability and leadership in order to ensure efficient and effective service delivery in the public sector. It is intended that the new model will bring about innovative administrative techniques that will ensure maximum efficiency in the production and delivery of public goods and services in public service. It is assumed that countries with weak institutions, especially Africa and Asia such as Thailand, Cambodia, Vietnam, Laos, Nepal, Nigeria, Tanzania, Zimbabwe, Mali, Uganda, Namibia, Democratic Republic of Congo, Ghana, Madagascar, etc can be using this modified model to deliver efficient and effective social/welfare services to the public.

\section{Literature Review}

One of the justifications for having MDAs in public organization is to serve as an instrument of service delivery (Ola, 1984; Finn, 2008). Adamolekun (1983) further lends credence to the statement by stating that the goal of MDAs is to deliver efficient welfare, social and essential services to the public. Improving service delivery is without doubt a cardinal pillar in the act of governance. So, managerial and governance reforms have been revolving around how to engender efficient and effective service delivery by MDAs. Indeed there exist numerous studies on local government and service delivery, of which Mass (1959), Oladosun (1981), Adamolekun (1983), Ola (1984), Aghayere (1987), Okeem (1989), and Lawal (2000) just to mention a few did a lot of critique and thorough studies on efficient service delivery by MDAs.

In the light of criticism over public sector expenditure on service delivery, the concept of New Public Management (NPM) was introduced in 1982. The concept embraces many new innovations such as managerialism, market-based governance, enterprenualism, and reforms that are widely deem necessary to bring about effectiveness and efficiency in the delivery of welfare, social and essential services. According to Hood (1991), NPM is seen as a politically neutral movement that is concerned with improving efficiency, effectiveness and accountability, especially in the area of infrastructural development and social/welfare services. The advent of the modified model intends to corroborate the concept of NPM in order to attain efficient service delivery by MDAs. Out of the numerous models that are being used for service delivery, governments of emerging and developing economies are still searching for new ways of improving public sector efficiency in order to address the issue of service delivery to the yearning of the fast majority of the citizens. Hudges (1994) posited that the model of public management will eventually change the way the public sector operates in term of service delivery. And Savoie (1992) argued that public managers require new skills and knowledge to be effective in delivering infrastructural development and social/welfare services. Smith (1996a) further lends credence by saying that managers had to develop new concepts, values, skills and new mindsets about public service. He went further by saying that the managers need to develop their staff, and engage them in the change processes in order to deliver efficient and effective social/welfare services to the public.

On the issue of funding and management of resources, transparency and accountability becomes an issue. Major feature of transparency and accountability is fairness. Thus, 
government must be accountable to the entire citizenry, and not just to a select group of stakeholders. Peters (2001) noted that the issue of equality raises important questions about accountability. How can public management be both flexible and fair? Accountability for finances and responsibilities reflect concern for how government does what it does, that is what is actually accomplished and how it is accomplished (Behn, 2001). Government is expected to use the available fund and other resources prudently, treat everyone fairly and must be able to accomplish public purposes. This implies accountability of performance, thus referring to the consequences of government action. Accountability of performance embraces the planning-oriented approach where accountability is given much importance as improved efficiency, effectiveness and service quality is emphasized. Behn (2001) concluded his work on democratic accountability by saying that existing institutions of accountability not only overemphasize accountability for finance and fairness, and undercut performance, but they undercut the capacity of government's productive units from achieving the results they were created to pursue.

On the other hand, the issues of fiscal federalism and decentralization of resources and responsibility need to be well established in the act of governance. This concept encourages efficient and effective delivery of infrastructural development and social/welfare services to the public. By enshrining fiscal federalism, either federal-state-local relations, state-state relations or state-local relations is given autonomy to develop their economic sector, and the proceeds from the economic activities or internally generated revenue (IGR) by either the federal, states and/or local governments are given autonomy to utilize the generated revenue in delivering infrastructural development and social/welfare services to the public through MDAs. And in order to address the issue of insufficient funding by other two tiers of government (i.e. state and local government), it becomes inevitable for the central government to decentralize funds and responsibilities among the three tiers of government so that the two tiers of government can deliver the required services to the public. Management of resources is viewed from view-lens of fiscal federalism and decentralization in order to give room for efficient and effective delivery of social/welfare services by MDAs.

Having dealt with funding and management of resources, the need arises to consider leadership quality and structure in MDAs. Public managers suppose to acquire skills, knowledge and possess professional competence in the administration of public resources, if efficient and effective social/welfare services are to be delivered. The issue of leadership within public organizations is assuming a new dimension and now extends to a range of staff with resource management responsibilities. New processes are emerging for leading change and focusing complex organizations (Vardon, 2000; Kotter \& Cohen, 2002). So, preference is given to leadership qualities and structure in the public sector in order to deliver efficient services to the public.

\section{Modified Quantitative Service Delivery Model (MQSDM)}

This paper aims to introduce a new modified model, having diagnosed other existing models used for service delivery by MDAs such as (Ablo \& Reinikka, 1998; Steffensen \& 


\section{Macrothink

Trollegaard, 2000; Reinikka, 2001; Xiao \& Sudharshan, 2002; Reinikka, Svensson \& Dehan, 2002; Dehn, Reinikka \& Svensson, 2003). It is observed with keen interest that most of the existing models focus on funding and management of resources, without giving consideration to managerial accountability, prudential management of resources, and leadership quality and structure in relation to efficient and effective service delivery by MDAs. In view of this argument, a new modified model on efficient and effective delivery of infrastructural development and social/welfare services is proposed, and baptized as Modified Quantitative Service Delivery Model (MQSDM). It is the belief of the authors that the modified model embraces all the attributes of other existing models, and other factors militating against adequate, efficient and effective service delivery to the citizens are taken care of.

The model is given below as:

The Modified Quantitative Service Delivery Model (MQSDM)

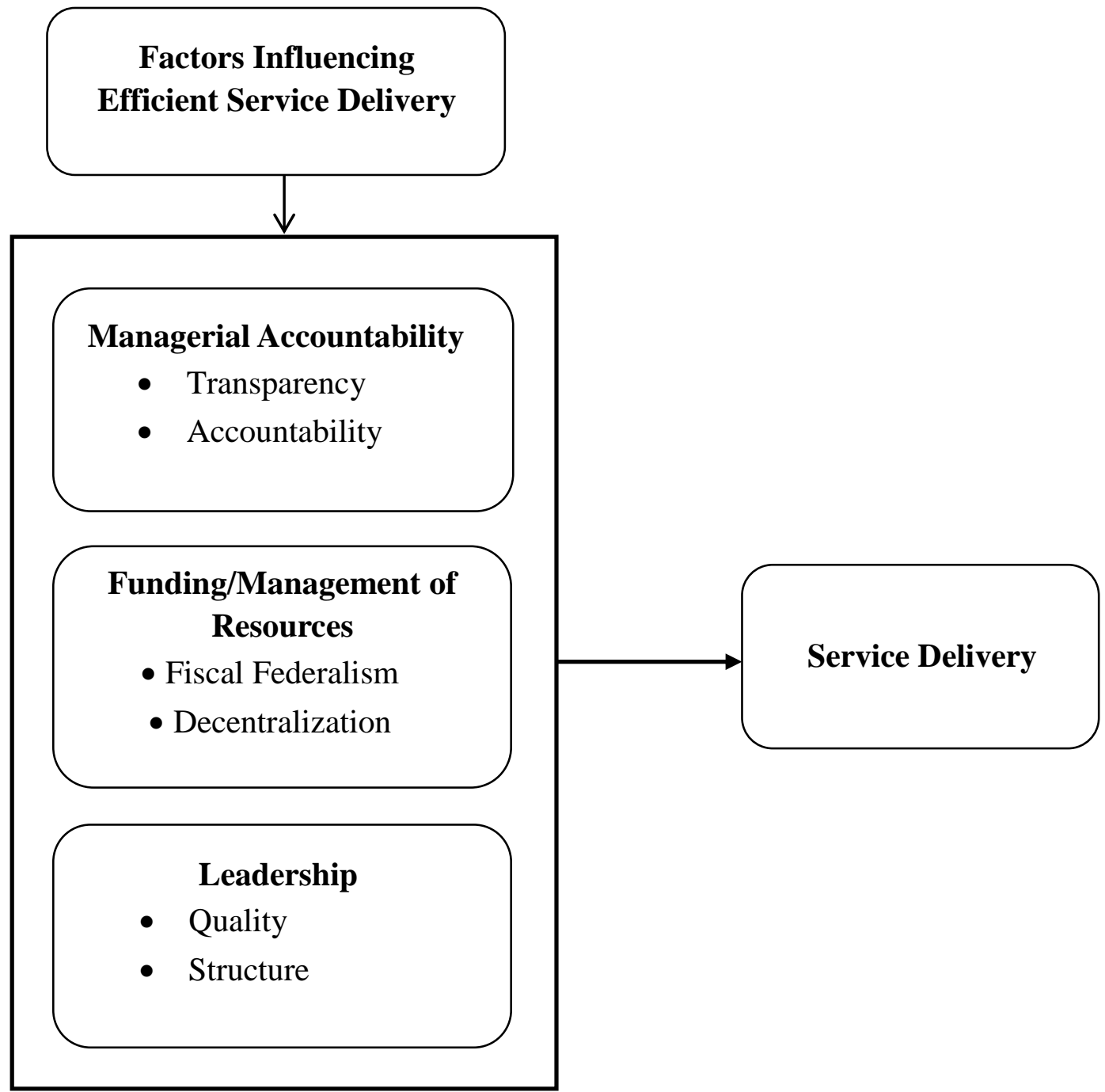

Source: Service Delivery by Local Government in Nigeria (Salihu et al. 2011) 


\section{Discussion}

This study provides a useful research model for exploring the challenges in assessing adequate, efficient and effective service delivery by MDAs. The issue of delivering efficient and effective social/welfare services is a continuous process, so government should embark on several institutional reforms in order to bring about efficient and effective service delivery. Most of the reforms should adopt different methodologies, strategies and models to improve on the delivery of social/welfare services. In fact, there are numerous studies on methodologies, strategies and models of improving social/welfare service delivery by MDAs by researchers such as Mass (1959), Oladosun (1981), Adamolekun (1983), Ola (1984), Aghayere (1987), Okeem (1989), Lawal (2000), and Salihu (2011) just to mention but a few. So, methods, strategies and models of delivering efficient and effective social/welfare services by all tiers of government are opened to intellectual discourse and further researches on ways of improving service delivery are often encouraged by public administrators.

As postulated by Davies (2000), the relationship between service delivery and managerial accountability is subject to some critical analysis. Lynn, Heinrich and Hill (2001) supported this argument by discussing governance in terms of "the regime of laws, rules, judicial decisions, and administrative practices that constrain, prescribe, and enable the provision of publicly supported goods and services". It therefore becomes pertinent to critically look into methods to ensure managerial accountability with reference to accountability and transparency in the public sector in order to ensure efficient and effective service delivery. Thus, it needs to be viewed from view-lens of discipline, openness, fairness, equity, transparency, accountability, honesty, integrity, credibility, etc in the management of public resources to ensure efficient and effective delivery of social/welfare services. It is when this is done that managerial accountability is guaranteed, that is, where public servants display credibility in the performance of their responsibility. If managerial accountability can be guaranteed in public organizations, then there is bound to be adequate management of public funds and resources. In return, there will be efficient delivery of services by MDAs.

Evidences from previous researches have been showing that more spending does not translate to corresponding social/welfare service delivery (Pritchett, 1996; Reinikka, 2001; Reinikka \& Svensson, 2001b; Gupta, Gauri \& Khemani, 2004). Filmer, Hammer and Pritchett (2000) posited further that lack of data, often formed constraints for researchers to conduct empirical studies on the relationship between public spending and service delivery outcomes. Salihu (2011) corroborated their position by saying that incomplete data resulted in incomplete inferences on the relationship between estimated budget on social/welfare services to be delivered and what is actually spent on service delivery outcomes. Also, empirical studies on how prudent are MDAs in their financial management and the impacts of this management of resources on service delivery are lagging. So, there ought to be binding relationship between managerial accountability and funding cum management of resources, if adequate and efficient welfare, social and essential services is to be delivered. It is therefore suggested that emphasis should be given to the issues of fiscal federalism and decentralization by all tiers of government. If fiscal federalism and decentralization is embraced, the rate of service 
delivery is bound to increase. And, managerial accountability and funding/management of resources should be integrated in order to achieve efficiency in the area of service delivery in the public service. With the integration of these two variables, the need arises to look into leadership quality and structure in the public sector.

There are changing conceptions and approaches with nature of public leaders and leadership style in the public service throughout the universe. Executive leadership, according to Campbell and Wyszomirski (1991) is beyond the level of senior service, but shows relationship between appointed and elected leaders. Leadership is said to be a product of an organizational context. This refers to the density of administrative competence. The question that most often raised is "how significant is leadership? The responses range from positions that leadership is either unimportant (Kaufman, 1981) or change is determined environmentally, to arguments that individual leadership does register an impact (Doig \& Hargrove, 1987; Sanders, 1998). Some scholars are of the opinion that leadership may be subtle (Rayner \& Theakston, 1999). A more inclusive approach is given by Rockman (1991), who sees leadership as interrelated with and dependent upon situation, factors, administrative culture, institutional forms and the agenda of political leaders.

Issues about the nature of and potential for leadership in the civil service are yet to be resolved. One strong argument is that civil service leadership is quite different from business leadership because of constitutional and political context. Senior civil servants cannot be rated as leaders in terms of the business management literatures because they are managers or clerks (Performance and Innovative Unit, 2001; Theakston, 1999). Yet, some management studies focus on corporate change across public and private sectors and the type of leader that are associated with different tasks (Stace \& Dunphy, 2001). But, there has been movement in the conceptions and analysis of civil service leadership. Specific leadership rather than leadership is now in focus. The issue of leadership within public organizations has acquired new dimensions and now extends to a range of staff with resource management responsibilities. New processes are emerging for leading change and focusing complex organizations (Vardon, 2000; Kotter \& Cohen, 2002).

Leadership in the opinion of the authors is the professional competence, skills and knowledge of leader in order to deliver the set- goals. This implies that leaders must be a goal getter. Considering the scope of this paper, a leader must be self discipline, well respected, and manage the resources of the organization efficiently in order to deliver welfare, social and essential services to the public. In light of this, leadership quality and structure needs to be integrated with the variables earlier mentioned (i.e. managerial accountability and funding/management of resources). With the integration, it translates to a new modified model on service delivery by MDAs, which is tagged as Modified Quantitative Service Delivery Model (MQSDM). This model is designed for professionals in order to ensure adequate and efficient service delivery by government through MDAs.

\section{Recommendation}

This paper recommends that the three major variables, namely managerial accountability, 
funding cum management of resources and leadership quality should be seen as main issue in delivering social services by MDAs. Since this model embraces both strengths and weaknesses of other existing models, modified quantitative service delivery model should be used in the public organizations to see whether there could be an improvement in the delivery of social/welfare services by MDAs in the public sector.

The model is equally good for countries with weak institutions because emphasis on managerial accountability, funding cum management of resources and leadership quality is elaborated. The integration of these variables will surely strengthen the public institutions, and in effect increase the delivery of services to the people. Therefore, MDAs should endeavor to use modified quantitative service delivery model and gauge the quantity of services delivered by MDAs.

It is the belief of the authors that if MQSDM is being used by MDAs for the delivery of required infrastructural development and social/welfare services, there is bound to be efficient and effective service delivery by MDAs in the public sectors. Therefore, the three variables of the model should be seen as the watch-words of MDA.

\section{Conclusion}

The discussion of the Modified Quantitative Service Delivery Model (MQSDM) has shown that research knowledge can be effectively transferred in different ways in order to achieve the design results. In this context, the major concern is to seek for ways of enhancing and ensuring adequate and efficient service delivery by government through MDAs. Besides, the paper is conceptual in nature that tries to show how managerial accountability, funding/management of resources and leadership quality cum structure are integrated together in order to achieve an improved way of ensuring efficient service delivery by government through MDAs.

There are still issues that can be raised using the new modified model in order to ensure efficiency in the provision of social/welfare and/or essential services by government through MDAs. So, further researches are required on the workability and comparability of other existing models with the new modified model in order to come out with more advance and/or acceptable model for attaining adequate, efficient and effective service delivery model by government through MDAs.

\section{Consideration for Future Study}

Study of this nature needs to be carried out continuously since professionals are seeking for methodologies, surveys and models that could be used to enhance and ensure adequate, efficient and effective provision of services to the public by various governments through their ministries, departments and agencies (MDAs). So, working groups with diverse experience on service delivery can be formed to look into ways of achieving efficient service delivery by government through MDAs, and offer suggestions for further study. 


\section{Macrothink}

\section{References}

Ablo, E. \& Reinikka, R. (1998). "Do budgets really matter? Evidence from public spending on education and health in Uganda". (Policy research working paper 1926). Washington DC: World Bank Development Researcg Group.

Adamolekun, L. (1983). Public administration: A Nigerian and comparative perspective. London: Longman.

Benton, J. E. (2002). Counties as service delivery agents: Changing expectations and roles. New York: Praeger.

Benton, J. E. (2000a). County government structure and service delivery. San Diego, California: A paper presented at the America Society for Public Administration Annual Conference, April 1-4.

Benton, J. E. (2000b). The impact of structural reform on government service provision. Atlanta, Geogia: A paper presented at the 2000 Southern Political Science Association Meeting, November 8-11.

Benton, J. E. (2002). County service delivery: Does government structure matter? Public Administration Review, 62(4), 471-479.

Dehn, Reinikka, \& Svensson (2003). "Survey tools for assessing performance in service delivery". In Bourguignon \& Pereira da Silva, eds. Evaluating the poverty and distributional impact of economic policies. Washington DC: Oxford University Press, and World Bank Research Group.

DeHoog, R. H. (1984). Contracting out for human services: Economic, political and organizational perspectives. Albany NY: Suny Press.

Ferris, J. \& Graddy, E. (1988). "The production choices for local government services". Journal of Urban Affairs, 10(2), 273-289.

Hood, C. (1991). “A public management for all seasons?” Public Administration, 69(1), 3-19.

Hughes, R. L., Robert, C. G., \& Curphy, G. J. (2006). Leadership: Enhancing the lessons of experience $\left(5^{\text {th }}\right.$ Edition). New York: McGraw-Hill/Irwin Inc.

Lawal, S. (2000). "Local government administration in Nigeria: A practical approach". Ibadan: University Press Limited.

McGill, R. (1988). "Planning for strategic performance in local government". Long-range Planning, 21(5), 77-84.

Newman, J. (2001). Modernising governance: New labour, policy and society. Thousand Oaks, CA: Sage Publishers. 


\section{Macrothink}

Journal of Public Administration and Governance

ISSN 2161-7104

2012, Vol. 2, No. 3

Ola, R. F. (1984). Local administration in Nigeria. London: Kegan Paul International.

Oyugi, W. O. (2000). Decentralization for good governance and development: The unending debate. Regional Development Dialogue, 21(1) spring, 3-22.

Park, K. O. (1996). Determinants of county government growth, in the American county: Frontiers of knowledge, edited by Donald C. Menzel, 34-50. Tuscaloosa, AL: University of Alabama Press.

Parker, D. (1995). Privatization and agency status: Identifying the critical factors for performance improvement. British Journal of Management, 6, 29-43.

Pavlov, P., \& Katsamunska, P. (2002). The relationship of leadership and new public management in Central Government: Bulgarian specific, Bulgaria: Varna Free University.

Performance and Innovation Unit (2001). Strengthening leadership in the public sector: A research study by the PIU. London: Cabinet Office.

Peters, B. G. (1996). The future of governing: Four emerging models. Lawrence, KS: University Press of Kansas.

Rakodi, C. (1997). The urban challenge in Africa: Growth and management of its large cities. New York: The United Nations University Press.

Rakodi, C. (2001). "Forget planning, put politics first? Priorities for urban management in developing countries". JAG, 3(3), 15.

Salihu, A. A. \& Khalil, S. (2011). Service delivery by local government in Nigeria: The delivery of primary education and healthcare service by local government in Nigeria. Germany: LAP Lambert Academic Publishing GmbH \& Co. KG.

Schneider, M. \& Kee, O. K. (1989). Metropolitan counties as service delivery agents: The still forgotten governments. Public Administration Review, 49(4), 345-352.

Smith, A. (1997). "Studying multi-level governance: Examples from French translations of the structural funds". Public Administration, 75(4), 711-729.

Steffensen, J. \& Trollegaard, S. (2000). Fiscal decentralization and sub-national government finance in relation to infrastructure and service provision (synthesis report of 6 sub-saharan Africa country studies). Washington, DC: The World Bank.

Stoker, G. (1998). "Governance as theory: Five propositions". International Social Science Journal, 15(2), 17-28.

UN-Habitat (2008). The state of Africa cities: A framework for addressing urban challenges in Africa, Nairobi, United Nations Human Settlement Program: 206. 


\section{Macrothink}

United Nations Economic Commission for Africa (UNECA) (2007). Public expenditure and service delivery in Africa: Perspectives on policy and institutional framework, Addis Ababa, United Nations Economic Commission for Africa: 62.

Xiao, Ye \& Sudharshan, C. (2002). "Efficiency of public expenditure distribution and beyond: A report on Ghana's 2000 public expenditure tracking survey in the sectors of primary health and education". (Africa region working paper series 31). Washington, DC: World Bank. 